\title{
An introduction to phytosemiotics: Semiotic botany and vegetative sign systems
}

\author{
Kalevi Kull \\ Dept. of Semiotics, University of Tartu, \\ Tiigi St. 78, 50410 Tartu, Estonia $^{1}$ \\ e-mail: kalevi@zbi.ee
}

\begin{abstract}
Asking, whether plants have semiosis, the article gives a review of the works on phytosemiotics, referring to the tradition in botany that has seen plants as non-mechanic systems. This approach can use the concept of biological need as the primary holistic process in living systems. Demonstrating the similarity between the need and semiosis, it is concluded that sign is a meronomic entity. A distinction between five levels of sign systems is proposed: cellular, vegetative, animal, linguistic, and cultural. Vegetative sign systems are those which are responsible for the morphogenesis and differentiation within an organism, thus belonging to all multicellular organisms.
\end{abstract}

Eine ganz ähnliche Stufenfolge ist in den Pflanzen, nur mit dem Unterschiede, daß die höhern Formen fehlen, wo die Zeugung unter dem Einflusse des Willens steht, weil der Wille und das gesammte animalische Leben den Pflanzen abgeht. Dagegen ist das Sprossen sehr gemein.

Karl Ernst von Baer (1864: 45)

\section{Why phytosemiotics? The problem of semiotic threshold}

The question - whether there is semiosis (a sign process) in plants, whether plants are ontologically semiotic systems - is a decisive question for biosemiotics. Because, if the answer is negative, there will be no reason to progress further from zoosemiotics, there will be

Also: Institute of Zoology and Botany, Riia St. 181, 51014 Tartu, Estonia. 
no need to extend the study of sign systems to the whole living world, to all of biology, as biosemiotics has set out to do. ${ }^{2}$

In his book $A$ Theory of Semiotics, U. Eco has formulated the problem of semiotic threshold: 'By natural boundaries I mean principally those beyond which a semiotic approach cannot go; for there is nonsemiotic territory since there are phenomena that cannot be taken as sign-functions' (Eco 1979: 6). At that time, Eco was quite certain about where this threshold is situated. ${ }^{3}$ He has stated: 'One must undoubtedly exclude from semiotic consideration neurophysiological and genetic phenomena, as well as the circulation of the blood or the activity of the lungs' (Eco 1979: 21).

However, few years later, a group of six leading semioticians published a collective work in which they argued for the placement of the semiotic threshold at the boundary of life (Anderson et al. 1984). Accordingly, the whole of biology was included into the semiotic realm.

Since then, research on biological sign processes has been growing quickly (for a review, see Kull 1999). Within the last two decades of the development of biosemiotics, it became widely accepted that the semiotic approach is an appropriate tool to describe all living systems, down to the first cells. There are many works in which the semiotic phenomena of the cellular level are analysed (Emmeche 1998, Hoffmeyer 2000, Kawade 1996, Pollack 1994). Quite naturally, semiotics of plants, or phytosemiotics, ${ }^{4}$ would be a part of this enterprise.

In many semiotic reviews, the existence of phytosemiotics is only mentioned, without real attempts to describe the theoretical models it can propose. For instance, W. Nöth (1990: 147) has remarked (although, over a decade ago): 'Whereas there has hardly ever been any doubt about the existence of signs in the animal kingdom, the assumption of semiosis in the sphere of plants, defended by the proponents of a new branch of semiotics called phytosemiotics, is still controversial'.

If, in the first edition of his Handbook, W. Nöth still hesitates to speak about phytosemiotics, then, in the second edition, he has already included a paragraph 'Exkurs zur Phytosemiotik' (Nöth 2000: 258259 ), to reflect the recent developments in biosemiotics. Also, when writing about ecosemiotics, he states that 'dieses Gebiet der Semiotik

\footnotetext{
On the biosemiotic program of research, see, e.g., Sebeok 1997, Hoffmeyer 1997, Kull 1992, 1999, Emmeche 1998, Sharov 1999, Wuketits 1998.

See also the paper by W. Nöth in the current volume.

4 For instance, V. Colapietro (1993: 160) has defined it namely like this, very briefly: phytosemiotics is 'the semiotics of plants'.
} 
überschneidet sich mit der Kultursemiotik, der Biosemiotik einschliesslich der Phytosemiotik und der bisher nur ansatzweise existierenden Physikosemiotik' (Nöth 2000: 250). In another work, Nöth (1994: 51-52) writes about 'spatial opposition in phytosemiosis'.

Since plants and animals do not cover all the non-human living world, it has naturally been asked whether we need additional terms for fungi, protists, and bacteria. 'If the phytosemiotic sluice was opened, the argument ran, there would be no end to new semiotics e.g., mycosemiotics, cytosemiotics, and so on' (Krampen 1992: 213). Indeed, T. A. Sebeok (1997) has argued for using the corresponding terms for each of the five kingdoms of life. Accordingly, reviews now exist about semiosis in unicellular organisms (Yates 1997) and fungi (Kraepelin 1997), in addition to the ones about animal semiosis.

Beside the problem of semiotic threshold (i.e., the question, on which side of the boundary plants belong), we, therefore, face, here, the next problem. This is the question, whether there may be anything special in plant semiosis in order to justify its distinction from the other fields of biosemiotics (i.e., the problem of distinction between semiotics of different kingdoms).

It may be necessary to stress that under phytosemiotics we do not mean the semiotics of botanical research, neither the existence of plants as signs in human communicative systems (the latter would still be a part of ecosemiotics, cf. Kull 1998, Nöth 1998; see also Krampen $1989)^{5}$, neither we will argue for any psychic phenomena in plants (cf. Nagel 1997). Our subject is confined to the question of the existence of (primitive) sign processes in plants. Phytosemiotics is the study of semiosis in the realm of plants. Also, we would like to exclude, here, the mechanisms which are general to almost all cells, and would like to focus on the semiotic phenomena which are specific to plants.

We use, here, the contemporary division of plants, according to which the kingdom Plantae includes only multicellular organisms with cellulose cell walls (i.e., all bryophytes and vascular plants). Most algae belong to the kingdom Protista (except the blue-green ones, which belong to Bacteria).

Thus, we ask in this paper, whether the formulation of phytosemiotics is justified, whether the inclusion of botany into semiotics is well grounded. In order to do so, first, we will give a review of the existing

For an ecosemiotic analysis of plants in human environment, including plant symbolism etc., see, for instance, Schmauks 1997, Schempp et al. 1997, Broek 1997. 
literature about phytosemiotics, and second, we will try to sketch some of the characteristics of its principal theoretical framework. ${ }^{6}$

\section{Twenty years of the term: Martin Krampen's phytosemiotic work}

In 1981, the paper 'Phytosemiotics' by Martin Krampen, which coined the term phytosemiotics and argued for its rights to exist, was published in Semiotica (Krampen 1981). This paper has been reprinted (with few changes, Krampen 1986a) and very often referred to. Later, Krampen has published several new versions of this paper (Krampen 1986b, 1997a) and a few analyses of some particular aspects of his approach (Krampen 1992, 2001), in addition to his writings on various ecosemiotic aspects of plants (Krampen 1994) and the usage of plants in architecture (Schempp et al. 1997).

Krampen has described the appearance of his view on the semiotics of plants as follows:

The establishment of phytosemiotics as a specific field of inquiry grew out of my in-depth study of Jakob von Uexküll's 'Theory of Meaning,?, which asserts that living beings down to the cell are 'autonomous' in their acceptance or refusal of signs from outside them, that there is a semiotic correspondence between the living organism and its specific surrounds (Umwelt), and that there is such a correspondence between the specific surrounds of different living beings according to a 'plan of nature'. (Krampen 1992: 213)

In his 1981 paper Krampen gives a brief review of Uexküll's biosemiotics and an analysis of Uexküll's view on the distinctive features of plants. He agrees with most of Uexküll's statements (e.g., the absence of effectors and receptors in plants, absence of a functional cycle, casing instead of Umwelt, meaning factors instead of meaning carriers). Krampen refers to the recent work on plant receptors and plant hormones, but tends to conclude that 'I would [...] like to maintain Jakob von Uexküll's conception denying plants the capacity of specialized receptor organs, and rather apply to what are called receptors in the [...] literature the term 'sensors', according to the parlance of cybernetics with respect to feedback cycles' (Krampen 1981: 194).

I want to thank Dagmar Schmauks and Winfried Nöth for drawing my attention to few interesting papers.

7 Uexküll 1940. 
Krampen also describes a few examples of animal-plant relationships, including the plant defence mechanisms against herbivores (Krampen 1981: 203-204).

The other topics in Krampen's paper mainly concern human relationships to plants - an area which does not say much about semiosis in plants themselves and would, thus, belong to ecosemiotics. He also provides quantitative data on the influence of plant gas exchange on the dynamics of oxygen concentration in a greenhouse, interpreting this in the context of plants' meaning for humans.

An interesting additional point made by Krampen states that plants' signs are indexes, animal ones icons, and human ones symbols: 'in plants, indexicality certainly predominates over iconicity. [...] Indexicality, on the vegetative level, corresponds to the sensing and regulating, in a feedback cycle, of meaningful stimulation directly contiguous to the form of the plant' (Krampen 1981: 195-196).

In the later versions of this paper, Krampen has added a few examples, e.g. on mimicry in plants (Krampen 1997a: 518), an apparently active defence by plants by sending chemical messages (Krampen 1997a: 517), on plant semiochemicals which attract the parasite hosts of the attacking caterpillars (Krampen 1992: 215), etc. The ecosemiotic part, i.e. the analysis of human-plant relationships, has also been developed. In a recent paper (Krampen 2001) the relationship between autotrophs and heterotrophs via oxygen and carbon dioxide has been given a semiotic interpretation.

The main point of Krampen's approach is formulated in his 'phytosemiotic hypothesis': 'while plants are autonomous living beings [...], their semiosis is different from that of human and animal subjects in such a way that it merits its own semiotic analysis' (Krampen 1981: 191-192). He also admits that 'the difficulty of this enterprise is to avoid anthropomorphizing the behavior of plants and to adopt, as an observer, the correct "phytocentric" perspective' (Krampen 1986b: 729).

\section{Jakob von Uexküll's statements about plants}

Jakob von Uexküll has written quite little about plants. In his Theoretische Biologie (Uexküll 1928) plants are almost not mentioned. However, in his late work (Uexküll 1940) he attempts to include plants in his consideration, in order to reach his fundamental conclusion: 'The 
question of meaning is, therefore, the crucial one to all living beings' (Uexküll 1982: 37). Below are a few statements about plants from this study.

Both animals and plants build living houses for themselves, i.e. their bodies, with whose help they lead their existence. [...] The plant has no nervous system, receptors, or effectors; therefore, no meaning-carriers, functional circle, perceptual, or effector cues exist for the plant. [...] The houses of plants lack mobility. Because they possess neither receptor nor effector organs, plants are not able to construct and be in command of an Umwelt.

The plant possesses no special Umwelt organs, but is immersed directly in its habitat. The relationships of the plant with its habitat are altogether different from those of the animals with their Umwelten. The building-plans of animals and plants are the same in only one respect. Both select precisely from among the stimuli that impinge upon them from the environment. (Uexküll 1982: 33)

Although plants may not have Umwelt, their relationship to the habitat is nevertheless different from the one of non-living things - it uses meaning. Thus, in the place of Umwelt, Uexküll uses the word Wohnhülle for plants.

Essential [lebenswichtige] stimuli also exist for plants; they emerge as meaning-factors out of all of those that impinge upon them from all sides. The plant encounters these stimuli, not with the help of receptor or effector organs, but because it has a living cell-layer that enables it to make its choice of stimuli from the dwelling-integument [Wohnhülle]. ${ }^{8}$ (Uexküll 1982: 34)

According to Uexküll, plants can utilise meaning via their form.

In the case of a plant, one cannot speak of functional circles. However, the meaning of the plant's organs (which also consist of living cells) lies in the utilization of the meaning-factors of its dwelling-integument [Wohnhülle]. It masters this task due to its shape, built according to a plan, and the exquisite organization of its components. (Uexküll 1982: 36)

He also gives few examples.

[...] the shapes of the plants and trees are adapted to the meaning-factor, wind, which they use in various ways to disperse their seed. [...] The rain is caught in the gutters of the tree-leaves, and is guided to the delicate root-ends under the earth. The sunlight is caught by the chlorophyll-

$8 \quad$ The translation of the last sentence, here, is slightly different from the one of 1982; cf. Uexküll 1940: 10. 
containing cells of the plant and is used for carrying out an intricate chemical process. The chlorophyll is not synthesized by the sun, nor is the gutter the product of the rain. (Uexküll 1982: 37)

The example of the form of tree foliage which directs rainfall towards the root tips is the one that Uexküll uses also in several other instances (Uexküll 1982: 49-51, 53).

\section{Plants in other biosemiotic studies}

As an important part of biology, botany should also have been included as subject matter in other works in the field of biosemiotics. However, plants, despite being most remarkable and common biotic components, have appeared very seldom as examples on the pages of these treatises.

John Deely, who has commented Krampen's paper in several of his writings (Deely 1986, 1990), has coined the term physiosemiosis to denote the role of semiosis in evolution in general, including the nonliving world, "whereby the physical interaction of existing things is channelled toward a future different from what obtains at the time of the affected interaction' (Deely 1990: 30). When speaking about plants, he emphasises an old tradition of thought according to which 'the life of plant exists within the animal itself precisely as base and part of its proper life' (Deely 1990: 97). Still, he hesitates to assign plants an ability of actual semiosis.

Rich as are the results of this method in Krampen's hands, I am not convinced that they succeed in establishing phytosemiotics on an equal footing. Or, to put it another way, I am not convinced that the communication among plants and between plants and the physical environment and the communication between plants and animals is, on the side of the plants themselves, fully an actual process of semiosis, such as it certainly is on the side of the animals. (Deely 1990: 98-99)

Deely also says that 'from Krampen's work I am convinced of phytosemiotics, but not of phytosemiosis' (Deely 1986: 103). This view is connected to 'a distinction between communication, which is virtually semiotic, and actual signification proper' (Deely 1990: 99). According to Deely (1990: 99), virtual semiosic phenomena involve thirdness latently, and he includes, here, endosemiotic, physiological and tropic phenomena, calling them all vegetative. 
Few interesting points are added by Thure von Uexküll (1986: 211), who says about vegetative signs that 'they are not signs for occurrences outside the plants, as there is no "outside" for vegetative systems.' He also writes:

Plants are solipsistic systems. Since they do not know about objects there is no point of describing them as subjects. They are only able to distinguish 'self' and 'nonself'. The signs which enable them to do this are iconic signs, i.e. perceptual signs for a decrease, operational signs for an increase of the similarity to 'self'. [...]

These facts also apply to the systems within our body. Cells are solipsistic systems as well, and endosemiotic signs are iconic signs of such systems. (T. v. Uexküll 1986: 211)

Jesper Hoffmeyer, in all his biosemiotic writings, has said remarkably little about plants (except for a few comments on Wohnhülle on the basis of Uexküll 1940, and references to some of Krampen's examples). However, he has argued for the existence of semiosis in cells, and, using the writing of A. Rayner (1997), has attempted to prove that fungi have semiosis (Hoffmeyer 2000).

I want to emphasise, here, a surprising controversy. Namely, when most authors, including Uexküll himself, state that plants have no Umwelt, they, at the same time, can attribute an Umwelt to some unicellular organisms. For instance, Uexküll describes the Umwelt of Paramecium, (Uexküll 1992: 342), and the Umwelt and Umwelttunnel of a parasitic microbe Plasmodium vivax (Uexküll 1922), unicellular organisms which both belong to the kingdom Protista.

The basic reason why it seems easy to speak about the Umwelt of unicellulars is evidently the distinguishability of their receptors and effectors. They have membrane receptors, and a flagella or cilia for moving their body. And even in the case when a cell cannot actively move, it has several other means to operate, for instance a mechanism for excretion. But the latter may also exist in plant cells. If so, then we can conclude that at least plant cells may have Umwelt. And if their cells have it, why not the organism as a whole?

Accordingly, we are reaching a hypothesis that the reason why plant Umwelt has usually been denied is because these authors have not studied plants in all the necessary detail. ${ }^{9}$ It may, thus, still be that plants possess an Umwelt, although a different kind.

\footnotetext{
9 Indeed, the authors cited (J. v. Uexküll, M. Krampen, J. Hoffmeyer) are not botanists.
} 
The problem is difficult not only for semiotics but also for biology. Ethology, the study of organisms' behaviour, only quite seldom devotes a chapter to the behaviour of plants. Neither has cognitive ecology (Real 1993) spoken about plants.

\section{Vegetative sign systems: Semiotic phenomena in the botanical field}

Krampen (1997a: 511) writes: 'What plants do have in any event are feedback cycles connecting sensors and regulators'. And he adds: 'Whether these processes satisfy Tembrock's (1975) strict definition, requiring a function cycle and signalling systems, is still too early to say. Phytosemiotics should one day be able to answer this question' (Krampen 1997a: 517). Thus, the question seems to converge very much in the precise definition of functional cycle. Still, most biosemioticians agree that Uexküll's (1992: 320-321) famous example about the behaviour of a tick represents a functional cycle. If this very simple reaction chain of a tick can be considered to be semiosic, then a plant ecophysiologist may evidently propose many examples of comparable compexity from his field. Below, we list a few common phenomena in plants that may be interpreted as functional cycles or their necessary components.

\section{Plant movements}

The statement that animals move and plants do not is scientifically incorrect. It is well-known that many plants can move their flowers or leaves towards a source of light, they can open and close their flowers, they move tendrils, the shoot and root apexes can turn if the gravitational field changes direction, etc. However, there is also an important difference between the movement of plants and animals, and, thus, a more correct statement says: most animals possess organs which can move the whole body, whereas plants cannot actively move the whole organism (except through growth) and may move actively only some of their parts. Thus, what is lacking in plants is not an active movement, but an active locomotion over distances (cf. Krampen 1997a: 511). 
Darwin has written a large work about plant movements (Darwin 1865). He has also picked up some profound similarities between animal and plant movements:

When the nerves and muscles of an animal are excited by galvanism or by the absorption of strychnine, the consequent movements may be called an incidental result, for the nerves and muscles have not been rendered specially sensitive to these stimuli. So with plants it appears that, from having the power of movement in obedience to certain stimuli, they are excited in an incidental manner by a touch, or by being shaken. Hence there is no great difficulty in admitting that in the case of leaf-climbers and tendrilbearers, it is this tendency which has been taken advantage of and increased through natural selection. (Darwin 1872: 178)

However, Darwin's main interest concerned the explanation of the evolutionary origin of these phenomena, and not the dissection of their proper mechanism.

Plant and animal movements differ remarkably in time scale. Plants are usually very slow in their reactions. This may be a reason why the behaviour of plant organisms cannot usually be recognised as meaningful per se. Thus, in order to make the plants' reactions recognisable to the human eye, one has to use speed photography, for example (cf. the emphasis made by Uexküll (1928) on the importance of cinematography for behavioural research).

According to the relationships to the source of excitation, the organ movements have been classified as tropic, nastic, and autonomic movements. In the case of tropisms, the movement depends on the direction of the signal, whereas the nastic movements are independent of the direction of the excitant. Autonomic movements do not require any external signal. ${ }^{10}$

An encyclopedic work by Haupt and Feinleib (1979) provides many examples of plant movement, also demonstrating, for example, the data which shows the availability of actomyosin in plant cells and the mechanism of contractile motor cells in Mimosa.

Thus, many cases are known where plant organs present an active movement which is coordinated with the whole life process of the individual. And 'a careful reconsideration of plant mobility might lead

\footnotetext{
10 The terminology of tropisms was developed particularly by Jacques Loeb, who distinguished between chemo-, helio-, geo-, etc. tropisms. Uexküll (1936) strongly criticized Loeb's approach, because the latter seemed to claim that the factors of movement are situated in the environment and not in the organism itself.
} 
to the hypothesis that there could be more to information seeking in plants than hitherto believed' (Krampen 1997a: 508).

\section{Plant receptors and effectors: Recognition in plants}

There exist many examples of mechanisms in plants where certain external signals are recognised by specialised cells or other plant structures, followed by a reaction chain that leads to an adaptive response in the same, or sometimes in another, organ of the plant. Here belongs, for instance, graviperception, which regulates the direction of growth in shoot and root tips (Volkmann, Sievers 1979). Another example can be the adaptive formation of reaction-wood as a result of changes in mechanical tension in root or shoot tissues (Wilson, Archer 1977). The third example may be the release of abscisic acid in roots in drying soil, which leads to stomatal closure and thus saves the plant from desiccation (Davies, Zhang 1991). There also exist photoreceptors, which are different from chlorophyll, reacting to certain light parameters and regulating plant differentiation.

Let us consider the following experiment with a seedling growing in complete darkness (on the resources either taken from the seed or mycotrophically from fungi). Due to gravitropism its shoot grows vertically. Let the pot with the seedling be covered by a cap which has two holes in it, both at some angle from the shoot. From one of these holes, we will give a low intensity radiation of a frequency that cannot be used for photosynthesis. The result may be that the shoot turns and grows through the irradiated hole. This experiment can be interpreted as demonstrating the adaptive response of a plant, where the plant uses the radiation of one kind as a sign for a possible light source suitable for photosynthesis. It demonstrates that the seedling is able to choose the direction of growth.

Thus, plants have selectively reacting structures that forward the signal to target mechanisms for a co-ordinated response.

Intercellular communication: cellular recognition and functional differentiation

In bacteria and protists, it is a common phenomenon that in natural conditions a new organism can develop in full from a single cell that 
is totally separated from any other cell of that kind of organism. In fungi, this also occurs, e.g. via conidia - the unicellular forms of vegetative reproduction. From conidia new mycelium can develop, which will form its own conidia, and so ad infinitum. In animals, this is not possible in natural conditions - in order to develop into a multicellular organism, a cell must have some communication with some other cells of its kind. In laboratory conditions the development of an organism from a single separated cell can be achieved, but this means that the natural communicative signals required for this in natural conditions will be replaced by artificial ones specially created in the growth media by the researcher. All vascular plants are, in this respect, similar to animals. However, in bryophytes it is possible that a new plant develops from a separated single-cell spore. This new plant can then reproduce vegetatively, via multicellular means, but it cannot produce new spores, and thus the full life cycle cannot occur. Thus, in all plants (as well as in all animals), the permanence of the intercellular communication system is an obligatory requirement for the life cycle to run. In most other large taxa this is not the case, since there exist many examples from the kingdoms of bacteria, protists, and fungi, where the intercellular communication system can be recreated anew, in natural conditions, from a single separate cell.

The role of intercellular communication concerns very much the overall regulation of growth and reproduction in most organisms. For instance, in the apical meristems of plants, the intercellular connections are considerably reduced in comparison to most differentiated tissues. Similarly, unlimited or malignant growth in animal tissues often occurs when the intercellular contacts (e.g., the cell-to-cell recognition mechanisms) are not working. Thus, decontextualisation is often related to the loss of growth control (Kull 1998: 353).

Differentiation, the formation of different types of cells in a tissue or a cell population, as a rule, is a result of certain communication mechanisms. If these do not work, the differentiation cannot take place.

\section{Inter-organismal communicative structures: sexual recognition and symbiosis}

Plants do have sex and sexual organs. This means that male and female gametes have to find and specifically recognise each other. If the gametes belong to different individuals — which is frequent in 
plants - the result will be biparental reproduction, and, consequently, the individuals categorise themselves into biological species. It has been demonstrated earlier that categorisation on the basis of selective recognition can be interpreted as a general phenomenon in semiotic systems (Kull 1992, 1993). Communication is responsible for the emergence of certain spatial or temporal structures - communicative structures - among which the biological species is one example.

It can be seen, particularly among plants, that there may also exist such taxa (i.e., of the above-species rank, usually of the level 'subgenera') that do not include any biological species. These are the cases where biparental reproduction has been lost (e.g., in Hieracium). Among animals, no good examples of this kind are known.

Among the communicative relationships between the specimens of different species, the most well-known examples belong to symbiotic or parasitic relationships. These exist between different plant species (e.g., between Cuscuta and Urtica), but even more widespread are those between plants and fungi (e.g., mycorrhiza) or plants and bacteria (e.g., Trifolium and Rhizobium). The statement that every symbiosis represents a semiosis has been repeatedly expressed in biosemiotic literature (see for instance Anderson et al. 1984, Kull 1999b).

Plant-animal relationships have seemingly been the area most often used for finding examples of communication-like phenomena in plants. This especially concerns plant pollination mechanisms, which show a great variety of fascinating forms. Darwin has studied several examples of plant-animal relationships, particularly those related to pollination by insects and the behaviour of insectivorous plants (Darwin 1875, 1984). He has pointed out the richness in plant forms, which is comparable to that of animals, e.g., in his book about orchids (Darwin 1984: 1): 'The object of the following work is to show that the contrivances by which Orchids are fertilised, are as varied and almost as perfect as any of the most beautiful adaptations in the animal kingdom.'

\section{Mimicry in plants}

Mimicry is one of those rare phenomena which have been counted as semiotic even by those researchers who generally do not accept that biosphere may be included into the semiotic sphere (cf. Maran 1999). The reason for this comes from the apparent and evident deception process that is the core of mimicry. However, most of the impressive 
examples of mimicry come from the animal kingdom. If a plant is involved in a mimicry situation, then it may not be clear whether the whole adaptive evolution could not be attributed only to the animal partner. Still, there are several examples, described, which are hard to interpret without an active adaptation from the side of the plant (for a review, see Wickler 1968, Wiens 1978, Komárek 1998: 279-283).

\section{'The meaning-utilisation by form' reconsidered}

One of the interpretations of Uexküll's example of the oak-tree and rain is as follows:

To put it in the common semiotic terminology: the leaf's [actually, the crown's - K. K.] form is the interpretant and the physical behavior of the raindrop [or rain] is the signifier. The code coupling leaf and raindrop [or, tree crown and rainfall] is the oak tree's need of liquid for transporting nourishing salts into its cells. (Krampen 1997a: 512)

If this situation is viewed in detail, one may notice that the growth of roots depends on the distribution of water in the soil. If the moisture conditions are more suitable in the region of the crown's edge projection on the ground, then this will also be the region of maximum density of fine roots, due to the sensitivity of roots to moisture. Therefore, what we have here is an example of a functional cycle, where the shortage of water leads to root elongation, until the roots reach the site with sufficient moisture. Further on, the same roots supply the leaves with water, and the crown can grow in diameter only if the roots have reached the suitable spatial distribution. Thus, indeed, the correspondence between the spatial placement of leaves and roots will be achieved due to a functional relationship that has originated from a specific biological need.

\section{Biological needs, vegetative needs, and semiosis}

A basic problem that still remains is: what makes the phenomena, described above, different from usual physical feedback mechanisms. Why it is not sufficient to apply a (bio)physical description to them, why do we in addition need a semiotic one?

Limiting myself to referring to the studies which argue for the holistic features of living processes (Elsasser 1998, Rosen 1991) or de- 
scribe in detail the characteristics of biological semiosis (Emmeche 1998, Hoffmeyer 2000, Sharov 1999), I will further analyse here the notion of biological need.

Life starts with needs. An existence of needs can be taken as a distinctive characteristic of living systems. If all the needs of an organism or its cells are removed, it will become a dead body.

Despite of its wide usage in biological literature, biologists lack a scientific definition of biological need. In order to go on in the discussion, I define this notion, here, using semi-cybernetic terminology: $a$ need is an expected input which regulates the output until the input reaches what it has expected. Thus, need is a situation when lack of something regulates operation for its sake.

This corresponds nicely to the explanation of the word need given, e.g., in the Webster's Dictionary. Need is defined simultaneously as (1) something necessary, useful, or desirable, and as (2) a lack of something necessary, useful, or desirable.

A stone does not have needs. When we say that a car needs petrol in order to move, then this is not the car itself which needs petrol, but the petrol is needed due to a human who wants to drive. However, plants themselves need light in order to assimilate carbon dioxide and grow.

Need is not just a feedback, in the same way that functional cycle is not just a feedback. In the case of functional cycle, the output is not deterministically caused by input; the input is related to that particular output due to the 'input expected'. The lack of expected input is related to certain output because it stands for the expected input. ${ }^{11}$ Thus the functional cycle is rather feed-forward, in the sense of Robert Rosen.

What distinguishes an action of physical cause from an action of sign, is that in the latter the effect that follows is not due to this cause, but is only explainable through something it stands for. In this way we can see the similarity between semiosis and the process of need.

\footnotetext{
11 One may ask whether there exist any 'unexpected inputs' for an organism? The answer is, certainly - yes. All those factors, for which an organism has no system of recognition or perception, i.e. which cannot be recognised by the organism, are in this sense 'unexpected'. This may be a sound for a deaf, or X-rays for an animal. The boundary between the 'expected' and 'unexpected' in this sense coincides with the boundary of Umwelt and non-Umwelt in the sense of Uexküll. On the other hand, the 'unexpected' input also can change the organism's behaviour, like in the case of damage caused by X-rays. Therefore, for an observer, a resulting change in behaviour cannot be a sufficient criterion for the distinction between the 'expected' and 'unexpected' inputs. Cf. also Barham 2000: 16.
} 
Still, a few other conditions need to be fulfilled in order to constitute a sign relation, or a need. First, one and the same factor has to be able to cause several different effects in the same system. Otherwise it is simply a physical factor, and cannot be a sign vehicle. And second, several different factors have to be able to lead to one and the same effect in the system. Otherwise one of the factors cannot stand for something else. Thus, the relation, or mapping, between the factor and effect has to be both one-to-many and many-to-one, in order to make a sign relation possible. ${ }^{12}$

And yet this is not enough. There should also be a memory. Memory means a capacity to store and to forget. That is, it should be possible that a current effect has an influence on an effect which will take place later, as a result of the same factors. If so, then we have the necessary conditions for a learning event to take place. It is a secondary problem, here, whether the memory is realised as a genetic, or epigenetic, or a neural one.

If life is just the operation of needs, then it might be possible to view biology as an analysis of needs.

A feedback in a mechanistic homeostat is a deterministic cycle. When a need appears, it will be indeterminate (cf. the discussion about the indeterminacy in Hoffmeyer 2000). During the formation of a sign, or a need, the connection between the input and output becomes canalized. But despite canalization, the potential multitude remains, and this enables the search to occur. A potential to make a search, or to seek, is evidently a general feature of functional cycles.

Thus, the organic forces are needs. And certain basic needs are those that descend. Biological evolution (as well as development), consequently, can be viewed as the differentiation of needs.

Need is also a holistic feature, being something emergent. The holistic behaviour of need follows also from its mapping relation, as described above. Differentiation of needs, therefore, is like differentiation of a whole into parts. Needs are characterised, usually, as biological functions. ${ }^{13}$ Thus, when a function is differentiating, then the functional connection does not disappear. And if this is true, then the functional connection can be kept even, for instance, in the differentiation

\footnotetext{
12 One can notice that these conditions are fulfilled for enzyme systems, as well as for neural nets.

13 This corresponds well to the functional explanation of biological traits via viability explanation. 'Viability explanations relate traits of organisms and their environments in terms of what an individual needs' (Wouters 1995: 435).
} 
of organisms into autotrophs and heterotrophs. This is Krampen's last example about the connectedness between plants and animals via mutual supply.

From the identification between needs and signs, or the need process and semiosis, as we have argued above, we now receive a fascinating statement: sign is always a part - a meron.

If so, then we can draw a line from a biological need to all possible types of signs, and also say that biological purpose originates from vegetative needs. $^{14}$

When Deely (1990) finds that the most general phenomenon related to semiosis of any kind is evolution, I would argue that evolution, as a temporal change, may also occur without the involvement of any semiosis, as it appears in the evolution of stars or many other nonliving dynamic systems, or in certain cases probably also in the evolutionary changes of living systems. A more appropriate candidate for a generally semiotic process may be a need, as it occurs in all organisms, beginning from cells.

Following the definition of need, above, one can hypothesise that the principal difference between plants and animals, in the functional aspect, has something to do with the form of expected input. In case of animals, these are usually much more complex, due to the integrating power of nervous system. For instance, it is probably unthinkable that the expected input may be temporally structured in the case of plants, whereas it often is so for animal perceptual signs.

\section{Meronomy of signs and needs}

Classification can be carried out in two ways. If we classify independent objects, we carry out taxonomy, and get taxa. But if we classify parts of a whole, this is meronomy, where we make a distinction between merons. Thus, in the case of the classification of sign vehicles, we have taxonomy, whereas when classifying signs as components of

\footnotetext{
14 One can see here certain similarity to some statements of the botanist and geneticist E. Sinnott (1950), who has argued that there seems to be in every living organism a sense of its inner subjective relation to its bodily organization that guides and controls vital activities towards specific ends. In other words, "the pattern or tension set up in protoplasm, which so sensitively regulates its growth and behaviour, can also be experienced, and this is the genesis of desire, purpose, and all other mental activities" (Sinnott 1950: 48).
} 
a sign system, we have to carry out meronomy (Meyen 1977, 1990, Schreider 1983).

Taxonomic classifications are based on various similarity relations. Context may have only secondary importance in taxonomy. Meronomic classification describes the functional differentiation of a system. Context cannot be broken in merons, because, through this, the relationship with the whole is kept.

'A difference that makes a difference' is a well-known definition of information by Gregory Bateson, but this is also the basis of any functional classification. Meaningful information is always 'a part of'. This is exactly the difference between structural and meaningful information. If there is no part-whole relation, there is no meaning. Still, without any ontological part-whole relationship, the measurement of structural information is applicable.

Meaning is made by part-whole relations, and, therefore, semiotics is meronomy. There is no signification without functional differentiation.

What is said here about sign, also belongs to the concept of need.

\section{Typology of sign systems: Vegetative sign systems}

A problem that semiotic biology faces from the very beginning is terminological. Starting, e.g., with the process-structure dichotomy, the biology of the last half century is not well fitted to the holistic understanding of its objects.

Until the beginning of the 20th century, the distinction between vegetative, animal, and intellectual phenomena was well accepted in biology. The analysis of instinct, as different from both vegetative and intellectual aspects of life, constituted a developed part of scientific discourse and of the professional biological intuition. However, since this distinction has not been supported by corresponding principal classes of biological mechanisms, it disappeared, step by step, from the textbooks and biological theory. Another reason for this change is seemingly connected to the fall of the teleological view that has largely served as a basis for that approach.

There has been a well-known debate about the concepts of primary and secondary modelling systems. According to the initial formulation by Lotman, language is the primary modelling system, whereas culture comprises the secondary one. Later, Sebeok has argued that there 
exists a zoosemiotic system which has to be called the primary one, leaving the secondary status to language, and the tertiary one to culture (e.g., Sebeok 1994). Sebeok's view has been supported by many later authors (cf. Moriarty 1994).

Now, speaking about the sign systems in plants, we are facing the problem of the inappropriancy of this classification again, due to the great differences between animal and vegetative signs.

It is seemingly appropriate to distinguish between sign systems and modelling systems. The modelling relation assumes an ability to imitate. Plants cannot imitate. But what plants have is a readiness toward certain events in their surroundings. Considering, as stated above, that plants do use signs, we are reaching a new classification, which is different for sign systems and modelling systems.

Thus, we can distinguish between five levels of sign systems.

1) Cellular sign systems. This is the sign system of any bacterial cell. Its characteristic processes are enzymatic recognition and membrane reactions. Its inheritance system combines the epigenetic and genetic. Described, e.g., by T. v. Uexküll (1985: 104-106); cell has no Umwelt, but dwelling integument (Wohnhülle). It is characterised by microsemiosis. According to Yates (1997: 458), microsemiosis 'does not address communication between cells or among cell complexes'.

2) Vegetative sign systems. This includes the communication between the tissues in multicellular organism. It is the system that is responsible for the genesis of multicellular biological form, the whole morphology of the body. The basic inheritance system here is epigenetic. Morphogenesis and cell differentiation are its typical representatives. In this sense, vegetative sign systems are not confined to plants they may occur in all multicellular organisms.

3) Animal sign systems. This is the senso-neuro-muscular system, the one that is responsible for the behaviour of a motile animal organism. The basic inheritance system, here, is neuro-humoral (or behavioural, according to Jablonka et al. 1998). Its characteristic feature is the existence of complex Umwelt.

4) Linguistic sign systems. This corresponds to the primary modelling system (natural language), according to Lotman (or secondary modelling systems, by Sebeok 1994). Differently to the animal sign system, it has syntactic signs (Bickerton 1990), and is principally symbolic (Deacon 1997). Its characteristic feature is the existence of symbolic language. 
5) Cultural sign systems. This corresponds to the secondary modelling systems, according to Lotman (or tertiary modelling systems, according to Sebeok 1994). Their characteristic features include the existence of artistic, ideological, ethical, etc. structures.

This, or similar, type of hierarchy has, of course, been proposed earlier, many times. Here, the distinctive aspect and emphasis is placed on the basic differences in semiotic features and characteristics of these levels.

A history of this typology goes back, for instance, to the classical distinction between anima vegetativa, anima sensitiva, and anima rationale. Already the doctrine of Thomas Aquinas included a view that in the first stage of embryonic development, the vital principle has merely vegetative powers; then a sensitive soul comes into being, educed from the evolving potencies of the organism - later yet, this is replaced by the perfect rational soul, which is essentially immaterial and so postulates a special creative act (cf. Ingensiep 1999). Thus, this whole story about the semiotic phenomena of plants is very much reminiscent of an old discussion, where the schoolmen assign some sort of soul, an anima vegetativa, to plants, whereas others have thought that soul goes no further than consciousness.

\section{Conclusion}

Certainly, there are many other phenomena, in plants, which can be treated as the semiotic ones. The aim of this work was to describe few better-known examples, in order to demonstrate the existence of semiosis in plants, and accordingly, to argue for botany as a semiotic discipline. The living process, which is interconnected via needs, so much as it requires wholeness, has to be treated holistically. However, this is only one side of the coin. The extension of the concept of semiosis over biology requires, simultaneously, a clear understanding of differences between the types of semiosis. ${ }^{15}$ Only then, theoretical botany cannot be developed for long without taking into account the fundamental semioticity of its major subject. And this may lead to a better understanding of what is sign.

\footnotetext{
15 In this, the arguments for vegetative semiosis differ from the statements, for instance, about the 'Intelligenz der Blumen' (Maeterlinck 1907), or the equality of life and cognition (Heschl 1990).
} 


\section{References}

Anderson, Myrdene; Deely, John; Krampen, Martin; Ransdell, Joseph; Sebeok, Thomas A.; Uexküll, Thure von 1984. A semiotic perspective on the sciences: Steps toward a new paradigm. Semiotica 52(1/2): 7-47.

Baer, Karl Ernst von 1864. Das allgemeinste Gesetz der Natur in aller Entwickelung. In: Baer, Karl Ernst von, Reden gehalten in wissenschaftlichen Versammlungen und kleinere Aufsätze vermischten Inhalts. Erster Theil. St. Petersburg: H. Schmitzdorff, 35-74.

Barham, James 2000. Biofunctional realism and the problem of teleology. Evolution and Cognition 6(1): 2-34.

Bickerton, Derek 1990. Language and Species. Chicago: The University of Chicago Press.

Broek, Gerard J. van den 1997. Flowers but no fruit: The vast land of unsemiotized culture. Semiotica 113(3/4).

Colapietro, Vincent M. 1993. Glossary of Semiotics. New York: Paragon House.

Darwin, Charles 1865. On the movement and habits of climbing plants. Journal of the Linnaean Society of London (Botany) 9: 1-118. [2nd ed. 1875.]

- 1872. The Origin of Species by Means of Natural Selection, or the Preservation of Favoured Races in the Struggle for Life [6th ed.]. London: John Murray.

- 1875. Insectivorous Plants. London: John Murray.

- 1984. The Various Contrivances by Which Orchids are Fertilised by Insects. Chicago: University of Chicago Press. [1st ed. 1862.]

Davies, W. J.; Zhang, J. 1991. Root signals and the regulation of growth and development of plants in drying soil. Annual Review of Plant Physiology and Plant Molecular Biology 42: 55-76.

Deacon, Terrence 1997. The Symbolic Species. New York: Norton.

Deely, John 1986. On the notion of phytosemiotics. In: Deely, J. N.; Williams, B.; Kruse F. E. (eds.), Frontiers in Semiotics. Bloomington: Indiana University Press, 96-103.

- 1990. Basics of Semiotics. Bloomington, Indiana University Press.

Eco, Umberto 1979. A Theory of Semiotics. Bloomington: Indiana University Press.

Elsasser, Walter Maurice 1998. Reflections on a Theory of Organisms: Holism in Biology. Baltimore: The John Hopkins University Press.

Emmeche, Claus 1998. Defining life as a semiotic phenomenon. Cybernetics and Human Knowing 5(1): 3-17.

Haupt, W.; Feinleib, M. E. (eds.) 1979. Physiology of Movements (Encyclopedia of Plant Physiology, n.s. vol. 7.). Berlin: Springer.

Heschl, A. 1990. L=C: A simple equation with astonishing consequences. Journal of Theoretical Biology 145: 13-40. 
Hoffmeyer, Jesper 1997. Biosemiotics: towards a new synthesis in biology. European Journal for Semiotic Studies 9(2): 355-376.

- 2000. The biology of signification. Perspectives in Biology and Medicine 43(2): 252-268.

Ingensiep, Hans Werner 1999. Leben am Rande der Seelenordnung: Grundzüge einer Ideengeschichte der Pflanzenseele. Jahrbuch für Geschichte und Theorie der Biologie 6: 7-46.

Jablonka, Eva; Lamb, Marion J.; Avital, Eytan 1998. 'Lamarckian' mechanisms in darwinian evolution. Trends in Ecology and Evolution 13(5): 206-210.

Kawade, Yoshimi 1996. Molecular biosemiotics: molecules carry out semiosis in living systems. Semiotica 111(3/4): 195-215.

Komárek, Stanislav 1998. Mimicry, Aposematism and Related Phenomena in Animals and Plants: Bibliography 1800-1990. Prague: Vesmír.

Kraepelin, Gunda 1997. Mykosemiose. In: Posner, Roland; Robering, Klaus; Sebeok, Thomas A. (eds.), Semiotics: A Handbook on the Sign-Theoretic Foundations of Nature and Culture, vol. 1. Berlin: Walter de Gruyter, 488-507.

Krampen, Martin 1981. Phytosemiotics. Semiotica 36(3/4): 187-209.

- 1986a. Phytosemiotics. In: Deely, J. N.; Williams, B.; Kruse, F. E. (eds.), Frontiers in Semiotics. Bloomington: Indiana University Press, 83-95.

- 1986b. Phytosemiotics. In: Sebeok, T. A. (ed.), Encyclopedic Dictionary of Semiotics. Berlin: Mouton de Gruyter, 726-730.

- 1989. An ecological approach to semiotics. In: Koch, Walter A. (ed.), Evolution of Culture. Bochum: Universitätsverlag Dr. Norbert Brockmeyer, 117-133.

- 1992. Phytosemiotics revisited. In: Sebeok, Thomas A.; Umiker-Sebeok, Jean (eds.), Biosemiotics: The Semiotic Web 1991. Berlin: Mouton de Gruyter, 213-219.

- 1994. Pflanzenlesebuch: Pflanzenstudium, Pflanzennutzung, Pflanzenpoesie; der Wandel menschlicher Einstellung zu Pflanzen im Laufe der Geschichte. Hildesheim: Olms.

- 1997a. Phytosemiosis. In: Posner, Roland; Robering, Klaus; Sebeok, Thomas A. (eds.), Semiotics: A Handbook on the Sign-Theoretic Foundations of Nature and Culture, vol. 1. Berlin: Walter de Gruyter, 507-522.

- 1997b. Models of semiosis. In: Posner, Roland; Robering, Klaus; Sebeok, Thomas A. (eds.), Semiotics: A Handbook on the Sign-Theoretic Foundations of Nature and Culture, vol. 1. Berlin: Walter de Gruyter, 247-287.

- 2001. No plant - no breath. Semiotica, special issue about Jakob von Uexküll (forthcoming).

Kull, Kalevi 1992. Evolution and semiotics. In: Sebeok, T. A.; UmikerSebeok, J. (eds.), Biosemiotics: Semiotic Web 1991. Berlin: Mouton de Gruyter, 221-233.

- 1993. Recognition concept of species and a mechanism of speciation. Folia Baeriana 6: 133-140. 
- 1998. Semiotic ecology: different natures in the semiosphere. Sign Systems Studies 26: 344-371.

- 1999a. Biosemiotics in the twentieth century: a view from biology. Semiotica 127(1/4): 385-414.

- 1999b. Symbiosis is semiosis. In: Wagner, Edgar; Normann, Johannes; Greppin, Hubert; Hackstein, Johannes H. P.; Herrmann, Reinhold G.; Kowallik, Klaus V.; Schenk, Hainfried E. A.; Seckbach, Joseph (eds.), From Symbiosis to Eukaryotism: Endocytobiology VII. Geneva University Press, 663-668.

Maeterlinck, Maurice 1907. Die Intelligentz der Blumen. Die neue Rundschau 18: 1-29.

Maran, Timo 1999. A note on the semiotics of biological mimicry. Sign Systems Studies 27: 139-145.

Meyen, Sergey V. 1977. Taksonomiya i meronomiya. In: Voprosy metodologii v geologicheskih naukah. Kiev: Naukova Dumka, 25-33.

- 1990. Netrivial'naya biologiya (zametki o...). Zhurnal Obschej Biologii 51(1): 4-14.

Moriarty, Sandra 1994. Visual communication as a primary system. Journal of Visual Literacy 14(2): 11-21.

Nagel, Alexandra H. M. 1997. Are plants conscious? Journal of Consciousness Studies 4(3): 215-230.

Nöth, Winfried 1990. Handbook of Semiotics. Bloomington: Indiana University Press.

- 1994. Opposition at the roots of semiosis. In: Nöth, W. (ed.), Origins of Semiosis: Sign Evolution in Nature and Culture. Berlin: Mouton de Gruyter, 37-60.

- 1998. Ecosemiotics. Sign Systems Studies 26: 332-343.

- 2000. Handbuch der Semiotik. (2., vollständig neu bearbeitete und erweiterte Auflage.) Stuttgart: Verlag J. B. Metzler.

Pollack, R. 1994. Signs of Life: The Language and Meanings of DNA. London: Viking.

Rausher, Mark D. 1996. Genetic analysis of coevolution between plants and their natural enemies. Trends in Genetics 12(6): 212-217.

Rayner, Alan D. 1997. Degrees of Freedom: Living in Dynamic Boundaries. London: Imperial College Press.

Real, Leslie A. 1993. Toward a cognitive ecology. Trends in Ecology and Evolution 8(11): 413-417.

Rosen, Robert 1991. Life Itself: A Comprehensive Inquiry Into the Nature, Origin, and Fabrication of Life. New York: Columbia University Press.

Schempp, Dieter; Frantz, Jürgen; Krampen, Martin; Weißinger, Sabine (eds.) 1997. Mensch, Raum und Pflanze. Braunschweig: Thalacker Verlag.

Schmauks, Dagmar 1997. Pflanzen als Zeichen. Zeitschrift für Semiotik 19(1/2): 135-149. 
Schreider, Julij A. 1983. Sistematika, tipologiya, klassifikatsiya. In: Schreider, J. A. and Shornikov, B. S. (eds.), Teoria i metodologiya biologicheskih klassifikatsij. Moskva: Nauka, 90-100.

Sebeok, Thomas A. 1994. Signs: An Introduction to Semiotics. Toronto: University of Toronto Press.

- 1997. The evolution of semiosis. In: Posner, Roland; Robering, Klaus; Sebeok, Thomas A. (eds.), Semiotics: A Handbook on the Sign-Theoretic Foundations of Nature and Culture, vol. 1. Berlin: Walter de Gruyter, 436-446.

Sharov, Alexei A. 1999. The origin and evolution of signs. Semiotica 127(1/4): 521-535.

Sinnott, Edmund W. 1950. Cell and Psyche: The Biology of Purpose. Chapel Hill: The University of North Carolina Press.

Stocker, Otto 1950. Das Umweltproblem der Pflanze. Studium Generale 3(2/3): 61-70.

Tembrock, Günter 1975. Biokommunikation. Reinbek: Rowohlt.

Uexküll, Jakob von 1922. Technische und mechanische Biologie. Ergebnisse der Physiologie 20: 129-161.

- 1928. Theoretische Biologie. 2te gänzlich neu bearbeitete Auflage. Berlin: Verlag von Julius Springer.

- 1936. Biologie in der Mausefalle. Zeitschrift für die gesamte Naturwissenschaft 2(6), 213-222.

- 1940. Bedeutungslehre. Leipzig: J. A. Barth.

- 1982. The theory of meaning. Semiotica 42(1): 25-82. [Translation of Uexküll 1940.]

- 1992. A stroll through the world of animals and men: A picture book of invisible worlds. Semiotica 89(4): 319-391. [1st ed. 1934.]

Uexküll, Thure von 1981. Welche Einstellung zur Natur ist die richtige? In: Sieber, Heinz G. (ed.), Mensch und Pflanze. Beiträge zum Projekt LOG ID: Leben mit Pflanzen (Fundamente Alternativer Architektur 4). Karlsruhe: C. F. Müller, 1-5.

- 1986. Medicine and semiotics. Semiotica 61(3/4): 201-217.

Volkmann, D.; Sievers, A. 1979. Graviperception in multicellular organs. In: Haupt, W.; Feinleib, M. E. (eds.), Physiology of Movements. (Encyclopedia of Plant Physiology, n.s. vol. 7.) Berlin: Springer, 573-600.

Wickler, Wolfgang 1968. Mimicry in Plants and Animals. New York: McGraw-Hill.

Wiens, D. 1978. Mimicry in plants. Evolutionary Biology 11: 365-403.

Wilson, Brayton F.; Archer, Robert R. 1977. Reaction wood: Induction and mechanical action. Annual Review of Plant Physiology 28: 23-43.

Wouters, Arno G. 1995. Viability explanation. Biology and Philosophy 10(4): 435-457.

Wuketits, Franz M. 1998. Zeichenkonzeptionen in der Biologie vom 19. Jahrhundert bis zur Gegenwart. In: Posner, Roland; Robering, Klaus; Sebeok, 
Thomas A. (eds.), Semiotics: A Handbook on the Sign-Theoretic Foundations of Nature and Culture, vol. 2. Berlin: Walter de Gruyter, 1723-1732. Yates, F. Eugene 1997. Microsemiosis. In: Posner, Roland; Robering, Klaus;

Sebeok, Thomas A. (eds.), Semiotics: A Handbook on the Sign-Theoretic Foundations of Nature and Culture, vol. 1. Berlin: Walter de Gruyter, 457-464.

\section{Введение в фитосемиотику: семиотическая ботаника и вегетативные знаковые системы}

В статье исследуется вопрос о наличии у растений семиозиса. Статья дает обзор имеюшихся работ по фитосемиотике, связывая ее с ботанической традицией, рассматривающей растения как немеханические системы. Такой подход позволяет использовать понятие биологической потребности как первичного холистического процесса в живых системах. Демонстрируя сходство потребности и семиозиса, автор приходит к заключению, что знак - это мерономическая единица. Выделяются пять уровней знаковых систем: клеточная, вегетативная, анимальная, лингвистическая и культурная. Вегетативные знаковые системы участвуют в морфогенезе и дифференциации организма и встречаются во всех многоклеточных организмах.

\section{Sissejuhatus fütosemiootikasse: semiootiline botaanika ja vegetatiivsed märgisüsteemid}

Artiklis uuritakse küsimust, kas taimedel esineb semioosis. Antakse ülevaate senistest fütosemiootika käsitlustest, seostades seda traditsiooniga botaanikas, mis vaatleb taimi kui mittemehhaanilisi süsteeme. See lähenemine lubab kasutada bioloogilise vajaduse mõistet, nähes selles esmast holistlikku protsessi elussüsteemides. Näidates vajaduse ja semioosise sarnasust, järeldatakse ühtlasi, et märk on meronoomiline üksus. Eristatakse viit märgisüsteemide tasandit: raku, vegetatiivne, animaalne, lingvistiline ja kultuuriline. Vegetatiivsed märgisüsteemid on need, mis osalevad organismi morfogeneesis ja diferentseerumises, esinedes seega kõigil hulkraksetel organismidel. 